Supporting Information

\title{
A Hydrophilic Azobenzene-Bearing Amino Acid for Photochemical Control of a Restriction Enzyme BamHI
}

Koji Nakayama, Masayuki Endo, and Tetsuro Majima*

The Institute of Scientific and Industrial Research, Osaka University

8-1 Mihogaoka, Ibaraki, Osaka 567-0047, Japan

$N^{\alpha}$-Boc-phenylazophenylalanyl-pdCpA. $N^{\alpha}$-Boc-4-aminophenylalanine was prepared by reduction of $N^{\alpha}$-Boc-4nitrophenylalanine with $10 \%$ palladium/carbon. Synthesis of $N^{\alpha}$-Boc-phenylazophenylalanine was carried out by the reaction of $N^{\alpha}$-Boc-4-aminophenylalanine with nitrosobenzene in $\mathrm{AcOH} / \mathrm{MeOH}$ solution (78\% yield). $N^{\alpha}$-Bocphenylazophenylalanine cyanomethyl ester was obtained by the reaction with chloroacetonitrile (51\% yield). $N^{\alpha}$-Bocphenylazophenylalanine cyanomethyl ester and a tetrabutylammonium salt of 5'-phospho-2'-deoxycytidylyl-(3'-5')adenosine (pdCpA) were coupled in DMF at it for $3 \mathrm{~h}$, and $N^{\alpha}$-Boc-phenylazophenylalanyl-pdCpA was purified by a reversed phase HPLC [linear gradient; 0-80\% acetonitrile containing $50 \mathrm{mM}$ ammonium acetate (pH 4.8) over $30 \mathrm{~min}$, Chemcobond C18 column ( $7.5 \times 150 \mathrm{~mm}), 260 \mathrm{~nm}$ ]. The collected fractions were combined and concentrated under reduced pressure. The product was finally lyophilized and stored at $-30{ }^{\circ} \mathrm{C}$. Yield $80 \%$. ESI-MS (negative); $\mathrm{m} / \mathrm{z}$ calcd for $\mathrm{C}_{39} \mathrm{H}_{46} \mathrm{~N}_{11} \mathrm{O}_{16} \mathrm{P}_{2}, 986.3$ [M-H]; found, 986.3 .
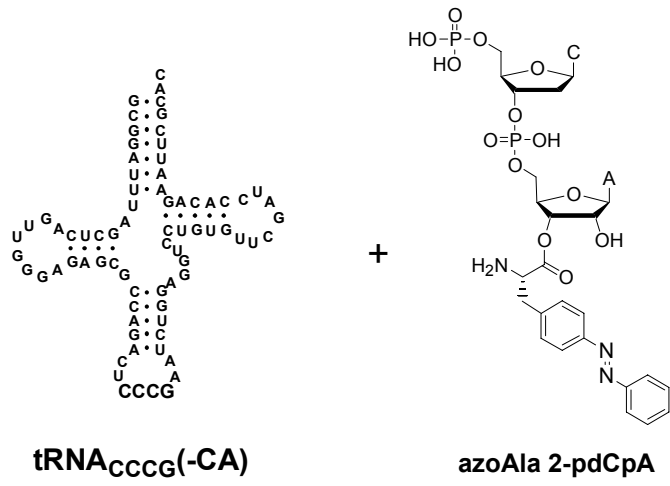

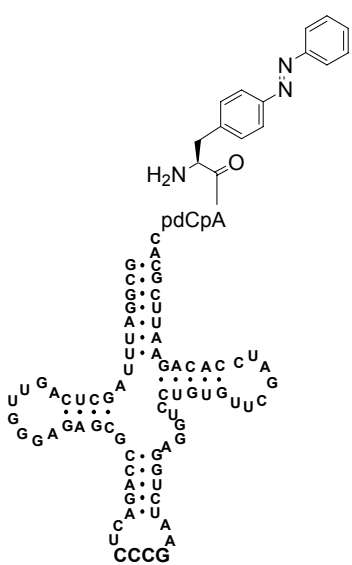

azoAla 2-tRNA

Scheme S1. Preparation of azoAla 2-tRNA ${ }_{\mathrm{CCCG}}$. 
Synthesis of phenylazophenylalanyl-tRNA ${ }_{\text {CCCG }}$ (azoAla 2-tRNA): A tRNA ${ }_{C C C G}(-\mathrm{CA})$ was obtained by in vitro transcription from a FokI-treated pUC19 plasmid containing T7 promoter and a synthetic yeast tRNA ${ }^{\text {Phe }}$ gene and purified by $8 \%$ denatured polyacrylamide gel electrophoresis (PAGE) (1). $N^{\alpha}$-Boc-phenylazophenylalanyl-pdCpA was treated with TFA on ice for $10 \mathrm{~min}$, then TFA was removed by $\mathrm{N}_{2}$ blowing, and the product was precipitated with diethyl ether twice and dried under reduce pressure. Ligation of phenylazophenylalanyl-pdCpA (azoAla 2-pdCpA) onto the tRNA $\mathrm{CCCG}(-\mathrm{CA})$ was carried out in a $30 \mu \mathrm{L}$ solution containing $5 \mu \mathrm{g}$ of tRNA $\mathrm{CCCG}(-\mathrm{CA}), 0.5 \mathrm{mM}$ azoAla 2 pdCpA, $50 \mathrm{mM}$ Tris- $\mathrm{HCl}$ (pH 7.5), $10 \mathrm{mM} \mathrm{MgCl}$, $10 \mathrm{mM}$ DTT, $1 \mathrm{mM} \mathrm{ATP,} \mathrm{BSA} 0.01 \%, 10 \%$ DMSO, and T4 RNA ligase (40 units) (2). The reaction mixture was incubated at $10{ }^{\circ} \mathrm{C}$ for $3 \mathrm{~h}$ and then quenched by addition of $3 \mu \mathrm{L}$ of $3 \mathrm{M}$ sodium acetate ( $\mathrm{pH}$ 5.2). The azoAla 2 - $\mathrm{RRNA}_{\mathrm{CCCG}}$ was desalted by ethanol precipitation, dried, and dissolved in $5 \mu \mathrm{L}$ of RNase-free water.

\section{References}

1. Endo, M.; Nakayama, K.; Majima, T. J. Org. Chem. 2004, 69, 4292-4298.

2. Nakayama, K.; Endo, M.; Majima, T. Chem. Commun. 2004, 2386-2387. 